\title{
The Relationship between Emotional Intelligence (EI) and the Malaysian University English Test (MUET) Performance among Technical Students
}

\author{
Nor Lailatul Azilah Hamdzah, Indra Devi Subramaniam \\ and Nadiah Zainal Abidin \\ Universiti Teknikal Malaysia Melaka, Malaysia \\ https:// orcid.org/0000-0002-5723-1569 \\ https:// orcid.org/0000-0002-9631-7031 \\ https://orcid.org/0000-0002-2771-2636 \\ Ruslan Hassan \\ Universiti Kebangsaan Malaysia, Malaysia \\ https:// orcid.org/0000-0003-2775-1050
}

\begin{abstract}
Past research has proven that emotional intelligence, the ability to justify one's emotion is integral in higher education, especially in teaching and learning of English Language. The main objectives of this study are to examine i) the relationship between emotional intelligence (EI) and MUET performance among undergraduate students in the technical university, ii) the correlation between emotional intelligence and MUET performance among 250 respondents from engineering and information and communication technology (ICT) courses and iii) can the level of emotional intelligence (EI) among undergraduate students in a technical university predict the students' performance in MUET? The cross-sectional survey design was used to collect the data from 250 respondents. The respondents were given the EQI questionnaire which had been constructed to collect the respondents' EI, which covers these aspects; self-awareness, self-regulation, empathy, self-motivation and social skills subskills. The results have highlighted that EI has a significant correlation with the students' MUET performance and can predict the students' MUET performance. Also, besides that, the findings show that there is a significant difference between the students' course and their EI level, thus implicating its dominant on education. Thus, from this study, as emotional intelligence plays important roles in determining the students' English language performance, emotional intelligence skills should be embedded in designing the English course. For future research, it is also recommended to discover the relationship of emotional intelligence traits and other language skills such as listening, speaking, reading and writing.
\end{abstract}

Keywords: emotional intelligence; Malaysian University English Test (MUET); Tapia's Emotional Quotient Inventory (EQI) 


\section{Introduction}

Mayer and Salovey (1993), as claimed by Mayer, Salovey and Caruso (2004) have defined the emotional intelligence as "the capacity to reason about emotions and of emotions to enhance thinking". Goleman (1995) stated that in determining one's triumph, the intellectual quotient (IQ) contributes only $20 \%$ while emotional intelligence governs the rest. Gibbs (2 October 1995) in Time article found that there is a significant correlation on how EI and IQ affect one another and lead to one's achievement. It has been discovered that the factor of failure among top executives in the U.S and Europe is the "classic emotional failings".

A dearth of past literature reveals on the significant role of emotional intelligence in determining academic success (Hassan, Sulaiman, and Ishak, 2009; Adeyemo, 2007; Marquez, Martin and Brackett, 2006). The inclusion of emotional intelligence gained prominence after its introduction in second language learning since the 1970s. Moreover, engineering education also claimed that the undergraduate engineers required a mastery of various skills which would enable them to fulfil their workplace requirements. Emotional intelligence skills include a set of skills which covers the skills of self-regulation, self-awareness, motivation, social skills and empathy. Emotional intelligence has contributed to learning abilities among the learners, communication skills and intercultural perspective. To address these issues, the study is aimed to analyse the relationship between emotional intelligence (EI) and MUET performance among undergraduate students in the technical university, to determine the correlation between emotional intelligence and MUET performance and to measure whether the level of emotional intelligence (EI) among undergraduate students in a technical university can predict the students' performance in MUET.

\section{Problem Statement}

Since 1999, The Malaysian Ministry of Education has introduced a Malaysian University English Test to prepare students to master an appropriate level of proficiency in the English Language. MUET, which is conducted by The Malaysia Examination Council consists of a listening test, a speaking test, a reading test and a writing test (Lee, 2004). This test is compulsory for the candidates who intend to pursue their study in tertiary institutions. The scores are divided into six bands, from the highly proficient user (Band 6) to the very limited user (Band 1). Previously, MUET examination had been conducted twice a year, but, due to its demand, it has been conducted for three times a year which is in March, in July and in November.

Former Minister of Higher Education of Malaysia, Dato' Seri Hishammuddin Hussein reported that deteriorating in English proficiency must be given a focus, as a majority of the students who enrolled in universities have low proficiency level (The Star, 27 January 2007). Based on the data provided by the Department of Academic Management (2016) in the technical university, there were more than 500 students who had sat MUET more than two times. The Malaysian Higher Education Blueprint 2015-2025 known as MEB (HE) has stressed on the importance of English proficiency among undergraduates to raise their competitiveness. In 2015, to deal with English Language issues among the 
undergraduates' students in higher education, Dato' Seri Najib Tun Abdul Razak has announced the new rules to enter the tertiary level. As the prerequisite entrance to public universities, the students for art and social science studies need to get Band 2 and they also must score Band 3 as a graduation requirement. Previously, art and social science studies need to have only Band 1 as the entrance requirement. The students from Science, Technology, Engineering and Mathematics (STEM) must score Band 3 for entrance requirement and Band 4 for graduation requirement. Also, besides that, Law and Medical students must score Band 4 as the prerequisite entrance and Band 5 for the graduation requirement. This has caused issues to the public higher institution in selecting the students in some fields (Bernama, 17 October 2014).

Emotional intelligence (EI) has been reported to have positive impacts on English Language proficiency among ESL learners. Emotional intelligence is a capability to reason one's emotion (Mayer and Salovey, 1993). Furthermore, Huseyin Oz et al. (2015) have suggested that emotional intelligence skills and ESL have a reciprocal connection. Many studies have proven that those who have emotional intelligence skills have a higher tendency to improve English Language as EI skills assist them in understanding the language better. Previous research has confirmed the interconnection between emotional intelligence and ESL learning. In additions, many types of researches have been completed to study the correlation between emotional intelligence and academic achievement. For example, in a study conducted by Petrides et al. (2004), it has been discovered that EI skills are compelling in assisting the students who score low IQ in facing the obstacles and stress in the academic endeavour. Petrides et al. (2004) also reported that students with low IQ and with high traits of EI could manage their stress and have better social interaction hence indicating an improvement in their studies. Sakinah and Nooreen (2013) have investigated the correlation between emotional intelligence and MUET achievement among matriculation students, but there is no research that has been done to technical students. As compared to other studies, this research is focused on the relationship between emotional intelligence and the MUET performance among the technical students in a technical university.

\section{Purpose of the Study and Research Questions}

Hence, the data from this study is intended to supply sufficient information via the explorations on the roles of EI in boosting and enhancing MUET performance among undergraduate students. Bar-On (2007) has highlighted that EI can be instilled, taught and learned. Subsequently, EI skills can be included in the educational policy and they can be integrated into the syllabus. As a result, the students' English performance will be enhanced and improved. Moreover, this study would help the university, the top management and the curriculum developer to structure and embed EI in pedagogical aspects.

The findings will provide a comprehensive understanding of emotional intelligence roles in improving the students' MUET performance among undergraduate students in the technical university. This can be expressed in the following research questions; Is there any significant correlation between the level 
of emotional intelligence (EI) among the undergraduate students in the technical university and the MUET performance? Can the level of Emotional Intelligence (EI) among undergraduate students in Universiti Teknikal Malaysia Melaka predict the students' overall performance in MUET?

\section{Literature Review \\ Emotional Intelligence (EI)}

Emotions have played crucial roles in individuals. The contributions of emotional intelligence in individuals have been highlighted by many parties such as psychologists, educators and researchers. Several studies have been carried out to study the concepts of emotional intelligence skills in individuals. Numerous studies and publications have addressed the concepts and definitions of emotional intelligence. Hen (2020) has pointed out that high emotional intelligence affects well-being, emotional self-efficacy and academic performance, as mentioned by Hen and Sharabi (2014).

Initially, Hassan et al. (2009) have mentioned that the word "emotion" was created from the Latin word "emovere" that has been defined as moving, happiness and hesitation (Mohd Azhar Abdul Hamid, 2006). Mayer et al. (2004) have mentioned that emotions "...occurs when there are certain biological, certainly experiential, and certain cognitive states which all occur simultaneously". There are emotions, which are more biologically oriented, and then there are complex emotions that are saturated with thoughts and cognition" (Geetu Orme, 2001). As mentioned by Geetu Orme, (2001), David Caruso, the codesigner of the Multifactor Emotional Intelligent Scale (MEIS) has described emotional intelligence as the capability to use the emotions intelligently to solve the problems and to live the life successfully. Geetu Orme (2001) has also derived emotional intelligence as the capability to alter the emotions, understand the emotions and act accordingly based on common sense. To conclude, feelings and emotions are used brilliantly in thinking, deciding and taking the proper action in one's life. Moreover, individuals have to be aware of their feelings and emotions to avoid other hitch and conflicts. In this study, Goleman Emotional Intelligence Model (1995) and Noriah (2004) are adapted which are self-awareness, selfregulation, social skills, motivation and empathy. These skills are categorized into five competencies which have been constructed into thirty items questionnaire.

\section{Malaysian University English Test (MUET)}

As referred by Lee (2004), the prospective students sit for the MUET exam as the mandatory requirement to enrol in public universities in Malaysia. Previously, in 2000, the English Language grade in the Sijil Pelajaran Malaysia (SPM) was referred to classify the students' language proficiency accordingly for university admission. Then, Souba and Kee (2011) posit on the use of MUET results to gauge students' proficiency levels. Besides, it has also been stressed as an admission requirement and as a placement test for many academic programmes. In contrast, this occurs more administrative issues in categorizing the students' proficiency (Chan and Wong, 2004). 
Many researchers and practitioners have suggested implementing a standardised assessment which could be used to evaluate the students' proficiency level. According to Lee (2004), MUET has been introduced in 1999 to cater to the issue of English classes that have not been prepared for pre-university students. Then, MUET has been fully implemented in 2000. MUET has been administered by The Malaysian Examination Council to decrease the gap in the use of English Language among students at secondary and tertiary level (Chan and Wong, 2004). Concomitantly, according to the National Education Policy, the MUET syllabus is shaped to enhance the students' language proficiency at the pre-university level and to assist the students to master the language excellently at a higher level.

\section{English Language Proficiency among Undergraduate Students}

In the engineering field, Venkatraman and Prema (2007) stated that the use of the English Language in the academic and professional lives of engineering students is very crucial. As such, Pendergrass et al. (2001) have claimed that, as the medium of instruction in science and math course, the English Language plays a vital part in enhancing the engineering students' performance, neither oral nor written communication. Since English is the principal international language of science, the academic performance of engineering and science students is influenced by their English Language proficiency (Pritchard and Nasr, 2004). It is because the professional reference texts for engineering and science students are mostly written in the English Language. This is supported by Joesba and Ardeo (2005) that claimed that as the English Language is considered as the international language, engineering students have to master the language effectively since all the reference sources such as books, research papers, handbooks, journal are written in the English Language.

Rea-Dicksin and Scott (2007) summarized that the English Language is critically important in engineering education to ease the interaction between the cultures. Besides, it has also been emphasised that the English Language is currently the communication requirement in the field of science and technology. The failure of the Upholding Bahasa Malaysia and Strengthening English Language (MBMMBI) have led to the abolition of the Teaching and Learning of Science and Mathematics in English (PPSMI) in Malaysia in 2012 (Moses and Malani, 2019). Moses and Malani (2019) have agreed that to uphold the government's aspiration to drive Malaysia as a developed nation, Malaysians have to master the English language. Furthermore, Ashairi, Mohamed and Melor (2017) also stated that the students could improve their English proficiency when learning science and mathematics in the English Language.

\section{Emotional Intelligence (EI) and English Language Performance}

Many researches have been done to examine the influence of emotional intelligence skills towards the learning of English Language. In a study done by Sedigheh and Ghasem (2011), it has been proven that there has been a dependable and significant relationship between EI and English language proficiency. The study was conducted to examine the correlation between EI skills and English language proficiency among Iranian high school students. Next, Huseyin Oz et al. (2015) have summarised that higher emotional intelligence could help ESL learners in language performance. They have also interpreted that individuals 
with emotional intelligence skills could understand the language better than others. They have declared that when individuals learn the English Language, their emotional intelligence skills would be improved. Saud (2019) has also found that in learning English Language, emotional intelligence is a crucial factor in determining the students' performance.

Zuhen (2016) has explained that language learning involves intrapersonal and interpersonal communication and interaction, that emphasise the emotional intelligence traits. Then, Goleman (1998), a well-known psychologist in the emotional intelligence field, has also indicated that emotional intelligence contributes to individual achievement. A study about the effects of emotional intelligence on academic performance has been done among 200 American students in Texas. In this study, Stottlemayer (2002) has revealed that academic achievement could be predicted by the respondents' EI level. Moreover, Rossiters (2003) has reported that individual differences, for instance, intelligence, aptitude, personality, motivation, attitude and anxiety influence second and foreignlanguage performance. Downey, Mountstephen, Lloyd, Hansen and Sough (2008) discovered that emotional intelligence skills influence the students' motivation, decision making strategy and planning. Consequently, this would affect students' academic achievement. Besides that, different studies have evaluated the relationship between EI and second language success, for example, Parisa (2013), Reza (2009) and Sedigheh and Ghasem (2011).

On the contrary, few studies have reported the insignificant correlation between emotional intelligence and language learning. For example, there was no correlation recorded between the EI traits and vocabulary learning among Iranian EFL learners at the intermediate level (Nesari, Karimi \& Filinezhad, 2011). Other than that, in a study done by Petrides and Furnham (2004), there was a negative correlation between emotional intelligence skills and foreign language anxiety.

\section{Research Methodology \\ Participants and procedure}

The methodology applied in this study comprises quantitative research that involves 250 respondents from two different fields and from six faculties in a technical university which include Faculty of Information Technology (FTMK), and five Faculties of Engineering. The respondents from an ICT course had represented The Faculty of Information Technology. Next, the data were also collected from the respondents from five different engineering faculties in the technical university to get the representatives from the engineering students.

The cross-sectional survey design was implemented in this study as the data was collected at one of time, and this design would give benefit to the researcher as it measures the current attitudes or practices. In this study, the cross-sectional survey design was used to examine the relationship between emotional intelligence skills among the undergraduate students in the technical university and the students' MUET performance. Thus, the current status of the students' emotional intelligence level could be identified. 
Other than that, the quantitative data was meant to investigate the relationships between the level of emotional intelligence and other variables; MUET performance, and programme. This study was designed by following the Goleman - Noriah EI Theory (2004), so the emotional intelligence domains used in this research are based on the EI domains that were constructed by Noriah (2004). The domains ascertained in emotional intelligence skills that have been used in this research are empathy, social skills, self-regulation, self-awareness, and motivation.

The target respondents were only those undergraduate students who have taken MUET examination because MUET performance is the dependent variable measured in this study. The population of this research consisted of 100 female students and 150 male students that represented the six faculties in a technical university. As a result, this study involved 250 respondents as the accessible population. The purpose of choosing the respondents from the Faculty of Information Technology (ICT) and Faculty of Engineering in the technical university is because these faculties focus on the niche area of the technical university as the Malaysian Technical University Network (MTUN).

As the technical university has five Faculties of Engineering, thus, the respondents from the engineering students were chosen equally from each Faculty of Engineering. Generally, $60 \%$ of the technical university undergraduates are male while the female students comprise $40 \%$ of the general population.

\section{Instrumentation}

This study adopted a set of a questionnaire from Tapia's Emotional Quotient Inventory (EQI) to acquire the quantitative data. The original set of the questionnaire consists of 41 items, though, this study has chosen only 30 items that are suitable with the context of the technical students. The instrument was designed by taking into account the consideration of six main elements which are demographic data, self-awareness, self-regulation, empathy, social skills, and motivation. This instrument has also been constructed based on Goleman's framework on emotional intelligence (1990).

This instrument has two sections according to the self-report based. The demographic data collected for this study are gender, age, race, faculty, year of study and the students' MUET performance. In this section, the questionnaires used open-ended and close-ended questions. Thirty items have been constructed for the second part of the questionnaire. All items were constructed based on the subskills of emotional intelligence, self-awareness (items no. 1, 2, 3, 4, 5, 6), selfregulation (items no. $7,8,9,10,11,12$ ), empathy (items no. 13, 14, 15, 16, 17, 18), social skills (items no. 19, 20, 21, 22, 23, 24) and motivation (items no. 25, 26, 27, $28,29,30)$. The respondents were instructed to rate the positive items on a fivepoint Likert scale ranging from 'never like me', 'occasionally like me', 'sometimes like me', 'frequently like me' to 'always like me'.

The Cronbach's Alpha in Statistical Package for Social Science (SPSS) software has been used to evaluate the reliability of the instruments. The output recorded a 
very high 0.946 for all 30 items for the overall internal consistency value. Thus, it can be concluded that the instruments have high reliability.

\section{Data Collection and Analysis}

Only one primary tool is used to collect information for the purpose of this study which is the questionnaire. Only survey method is used because the emotional intelligence instrument is adequate to investigate the impact of types of programmes on the levels of emotional intelligence among the undergraduate students in the technical university, to analyse the correlation between the level of emotional intelligence (EI) among the undergraduate students and their MUET performance and to examine whether the level of emotional intelligence (EI) among undergraduate students in a technical university can predict the students' performance in MUET.

The questionnaire, which is a form containing a set of questions and addressed to a statistically significant number of subjects as a way of gathering information for a survey is considered the best way of obtaining data especially for a large scale survey such as this one. The questionnaires were distributed to 250 respondents.

\section{Results and Discussion}

The analysis of the quantitative data presents the following aspects: - $i$. the significant difference in the level of emotional intelligence (EI) according to the students' programmes in the technical university. ii. the correlation between the level of emotional intelligence (EI) among undergraduate students in the technical university and their MUET performance. iii. Can the level of emotional intelligence (EI) among the undergraduate students predict their MUET performance?

The impact of types of programmes on the levels of emotional intelligence among the undergraduate students in the technical university

The findings obtained from the analyses of the data are given in the tables:

Table 1: The level of emotional intelligence among respondents

\begin{tabular}{|c|c|c|c|c|c|c|c|}
\hline \hline \multicolumn{2}{|c|}{ Group Statistics } \\
\hline & Course & $\mathrm{N}$ & Mean & $\begin{array}{c}\text { Std. } \\
\text { Deviation }\end{array}$ & $\begin{array}{c}\text { Std. } \\
\text { Error } \\
\text { Mean }\end{array}$ & $\begin{array}{c}\text { t- } \\
\text { Value }\end{array}$ & Sig. \\
\hline $\begin{array}{c}\text { Emotional } \\
\text { Intelligence }\end{array}$ & Engineering & 125 & 2.4720 & .43748 & .03913 & - & 0.00 \\
\cline { 2 - 8 } & ICT & 125 & 3.6200 & .45712 & .04089 & & \\
\hline \hline
\end{tabular}

An independent sample t-test was conducted to compare the level of emotional intelligence scores for the respondents from the engineering course and ICT courses. The analysis was done to answer research question 1 which is: RQ (1): Is there any significant difference in the level of emotional intelligence (EI) according to the students' programmes in the technical university? 
$\mathrm{H}_{0}$ : There is no significant difference in the level of emotional intelligence (EQ) according to the students' programmes at the technical university

$\mathrm{H}_{1}$.There is a significant difference in the level of emotional intelligence (EQ) according to the students' programmes at the technical university.

The findings show that there is a significant difference in the level of emotional intelligence for engineering course and ICT courses, t $(250)=-20.285, \mathrm{p}$-value $=$ 0.00 . The level of emotional intelligence among ICT students $($ mean $=3.62$, s.d. $=$ $0.46)$ is significantly different from the level of emotional intelligence among engineering students (mean $=2.47$, s.d. $=0.44$ ). in other words, students from the ICT courses have a higher level of emotional intelligence as compared to students from the engineering course. Thus, the null hypothesis is rejected.

Similarly, Sanchez-Ruiz et al. (2013) have elucidated that, as compared to other majors, the psychology students were recorded a higher score of EI skills. Concurrently, Sanchez-Ruiz et al. (2013) have also discovered that students from the electrical engineering and computer science course scored a lower level of emotional intelligence in comparison to students from the field of business and management. Further, other researchers have also advocated that respondents from the vocational and technical areas reveal lower scores on EI traits in comparison to those in the field of social science (Caste Jon et al., 2008; Sanchez Ruiz et al., 2013). Zuhen (2016) has suggested that the undergraduates who use ICT and media tools in ESL would be able to be attentive to their emotions than others. The findings of this study have highlighted that ICT and media tools assist the students in learning English (Zuhen, 2016). As affirmed by Petrides et al. (2016), Sanchez-Ruiz, Perez-Gonzalez and Petrides (2010), technical students indicate a lower score in terms of the emotionality score in comparison to students of arts. It can be concluded that emotional intelligence level among the students from a different type of courses and programmes are different. Thus, emotional intelligence skills must be integrated into designing the syllabus for the course, depending on the types of the course and programme.

The correlation between the level of emotional intelligence (EI) among the undergraduate students and their MUET performance

Next, to determine the correlation between the level of emotional intelligence (EI) among the undergraduate students in the technical university and their MUET performance, a Pearson Correlation was used. The result of the finding is portrayed in Table 2. The Pearson Correlation is conducted to justify the research question 2 which is: -

RQ (2): Is there any significant correlation between the level of emotional intelligence (EI) among the undergraduate students in the technical university and their MUET performance?

$\mathrm{H}_{0}$ : There is no significant correlation between the level of emotional intelligence (EQ) among the undergraduate students in the technical university and their MUET performance.

$\mathrm{H}_{1}$.There is a significant correlation between the level of emotional intelligence (EQ) among the undergraduate students in the technical university and their MUET performance. 
Table 2: The relationship between EI Level and the students' MUET performance

\begin{tabular}{|c|c|c|c|}
\hline \multicolumn{4}{|c|}{ Group Statistics } \\
\hline & & $\begin{array}{c}\text { EI } \\
\text { Level }\end{array}$ & $\begin{array}{c}\text { MUET } \\
\text { Performance }\end{array}$ \\
\hline \multirow[t]{6}{*}{$\begin{array}{l}\text { Emotional } \\
\text { Intelligence }\end{array}$} & $\begin{array}{c}\text { Pearson } \\
\text { Correlation }\end{array}$ & 1 & $.706^{* *}$ \\
\hline & $\begin{array}{l}\text { Sig. (2- } \\
\text { tailed) }\end{array}$ & & .000 \\
\hline & $\mathrm{N}$ & 250 & 250 \\
\hline & $\begin{array}{c}\text { Pearson } \\
\text { Correlation }\end{array}$ & $.706^{* *}$ & 1 \\
\hline & $\begin{array}{l}\text { Sig. (2- } \\
\text { tailed) }\end{array}$ & .000 & \\
\hline & $\mathrm{N}$ & 250 & 250 \\
\hline
\end{tabular}

The data in Table 2 shows that there is a very strong positive correlation $(r=0.706$, $\mathrm{p}<0.05)$ between the EI level and MUET performance. Thus, the null hypothesis is rejected. This data has described the hypothesis, $\mathrm{H}_{1}$ : There is a significant correlation between the level of emotional intelligence (EI) among the undergraduate students in the technical university and their MUET performance. By squaring the correlation and then multiplying by 100, it indicates that the EI level shares $49.8 \%$ of its variability with the students' MUET performance. It can be summed that the EI performance helps to increase the students MUET performance in a large percentage $(49.8 \%)$.

Table 3: The relationship between EI subskills and the students' MUET performance

\begin{tabular}{|c|c|c|}
\hline & & "MUET Performance \\
\hline \multirow[t]{3}{*}{ Self_Awareness } & Pearson Correlation & $.656^{* *}$ \\
\hline & Sig. (2-tailed) & .000 \\
\hline & $\mathrm{N}$ & 250 \\
\hline \multirow[t]{3}{*}{ Self_Regulation } & Pearson Correlation & $.659^{* *}$ \\
\hline & Sig. (2-tailed) & .000 \\
\hline & $\mathrm{N}$ & 250 \\
\hline \multirow[t]{3}{*}{ Empathy } & Pearson Correlation & $.654^{* *}$ \\
\hline & Sig. (2-tailed) & .000 \\
\hline & $\mathrm{N}$ & 250 \\
\hline \multirow[t]{3}{*}{ Social_Skills } & Pearson Correlation & $.607^{* *}$ \\
\hline & Sig. (2-tailed) & .000 \\
\hline & $\mathrm{N}$ & 250 \\
\hline \multirow[t]{3}{*}{ Motivation } & Pearson Correlation & $.606^{* *}$ \\
\hline & Sig. (2-tailed) & .000 \\
\hline & $\mathrm{N}$ & 250 \\
\hline \multirow[t]{3}{*}{ MUET Performance } & Pearson Correlation & 1 \\
\hline & Sig. (2-tailed) & \\
\hline & $\mathrm{N}$ & 250 \\
\hline
\end{tabular}


According to Table 3, the data reveals that there is a strong positive relationship $(r=0.656, p<0.05)$ between the self-awareness and the students' MUET performance. After squaring the correlation and then multiplying by 100 , it shows that self-awareness shares $43 \%$ of its variability with the students' MUET performance. In other words, it shows that self-awareness skill can help to increase the students MUET performance in a large percentage $(43 \%)$. For another subskill, for instance, self-regulation, there is a strong positive relationship ( $\mathrm{r}=$ $0.659, \mathrm{p}<0.05)$ between self-regulation and the students' MUET performance. Self-regulation shares about $43.4 \%$ of its variability with the students MUET performance. To sum, it helps the students MUET performance by $43.4 \%$. Then, there are also strong positive relationship between self-motivation $(\mathrm{r}=0.606, \mathrm{p}<$ $0.05)$, Empathy $(\mathrm{r}=0.654, \mathrm{p}<0.05)$ and students' MUET performance. These findings show that self-motivation helps the students MUET performance of $36.7 \%$, and empathy shares $42.7 \%$ of its variability with the students' MUET performance. Same goes with social skills that share $36.8 \%$ of its variability with the students MUET performance $(\mathrm{r}=0.607, \mathrm{p}<0.05)$. For motivation, it also recorded a weak positive relationship as well $(\mathrm{r}=0.083, \mathrm{p}<0.05)$ with the students' MUET performance. Maturity shares $0.68 \%$ of its variability with the students' MUET performance. It can be said that maturity level only contributes $0.68 \%$ for the students' MUET performance. Finally, spirituality also showed the same finding with other subskills as it recorded a strong positive relationship $(\mathrm{r}=$ $0.606, p<0.05)$ with the students' MUET performance. By squaring the correlation and then multiplying by 100 , it indicates that it shares only $36.7 \%$ of its variability with MUET performance. It helps the students to improve their MUET performance in about $36.7 \%$. It can be concluded that all subskills have shown a very positive relationship with MUET performance.

This finding in this research is consistent with research conducted by Khalil (2012), who has investigated the relationship between Iranian EFL Learners' emotional intelligence and their performance in TOEFL. TOEFL is an English placement test, which is similar to MUET in terms of purpose. In this research, Khalil (2012) indicates a significant and positive relationship between EI and TOEFL scores. The findings illuminate the fact that emotional intelligence has its impact on students' performance in English tests that measure their language proficiency in listening, speaking, reading and writing. In research done by Sakinah and Nooreen (2013), it has been proven that there was a significant relationship between the students' MUET achievements and emotional intelligence. The study had been conducted to examine the correlation between MUET achievement and emotional intelligence skills among matriculation students in Universiti Sains Malaysia. Seyed et al. (2014) have investigated the relationship between emotional intelligence and language achievement among university students in Iran. The finding appears to support the previous literature as there was a significant relationship between EI and language achievement score of the participants. Hasanzadeh and Shahmohamadi (2011) emphasised that students were more expressive and independent, have a high tendency to master the language successfully. Alavinia and Mollahossein (2012) stated that emotional intelligence skills are relevant in learning the language as compared to other subjects. 
Can the level of emotional intelligence (EI) among the undergraduate students predict their MUET performance?

Next, to study the relationship between those variables which are the level of emotional intelligence and the students' performance in MUET, the simple regression analysis was conducted. This simple regression analysis is run to explain the research question 3 which is:-

$R Q$ (3): Can the level of emotional intelligence (EI) among undergraduate students in the technical university predict the students' overall performance in MUET?

Table 4: Model Summary

\begin{tabular}{|c|c|c|c|c|}
\hline \hline \multicolumn{5}{|c|}{ Model Summary } \\
\hline Model & $\mathrm{R}$ & $\mathrm{R}$ Square & $\begin{array}{c}\text { Adjusted R } \\
\text { Square }\end{array}$ & $\begin{array}{c}\text { Std. Error of } \\
\text { the Estimate }\end{array}$ \\
\hline 1 & $.706^{\mathrm{a}}$ & .498 & .496 & .51170 \\
\hline \multicolumn{5}{|c|}{ Predictors: (Constant), Emotional Intelligence } \\
\hline \hline
\end{tabular}

This value in Table 4 indicates that $49.8 \%$ of the variances in the students' MUET performance can be predicted from the variable of the students' level of emotional intelligence. Thus, it can be said that the level of emotional intelligence among the undergraduate students in the technical university reliably predicts the students' MUET performance. It has been proven that emotional intelligence contributes to the students' MUET performance.

Table 5: Description of Regression

\begin{tabular}{|c|c|c|c|c|c|c|}
\hline \multicolumn{5}{|c|}{$\overline{A N O V A}^{a}$} & & \\
\hline \multicolumn{2}{|c|}{ Model } & Sum of & $\mathrm{df}$ & Mean & $\mathrm{F}$ & Sig. \\
\hline \multirow[t]{3}{*}{1} & Regression & 82.946 & 1 & 82.946 & 245.833 & $.000^{\mathrm{b}}$ \\
\hline & Residual & 83.678 & 248 & .337 & & \\
\hline & Total & 166.624 & 249 & & & \\
\hline \multicolumn{7}{|c|}{ a. Dependent Variable: MUET Performance } \\
\hline & b. $P r$ & (CON & $E m$ & ll & & \\
\hline
\end{tabular}

Based on Table 5, the p-value is 0.000 , which is lower than alpha level, $p<0.05$. It shows that the level of emotional intelligence among undergraduate students can be used significantly to predict the students' MUET performance. Furthermore, the description of the simple regression analysis is shown in Table 6 to provide justification for the result.

Table 6: Description of simple regression

\begin{tabular}{|c|c|c|c|c|c|c|}
\hline \multicolumn{5}{|c|}{ Coefficients ${ }^{a}$} & \multirow{3}{*}{$\mathrm{t}$} & \\
\hline & \multirow[t]{2}{*}{ Model } & \multicolumn{2}{|c|}{$\begin{array}{c}\text { Unstandardized } \\
\text { Coefficients }\end{array}$} & \multirow{2}{*}{$\begin{array}{c}\begin{array}{c}\text { Standardized } \\
\text { Coefficients }\end{array} \\
\text { Beta }\end{array}$} & & \multirow[t]{2}{*}{ Sig. } \\
\hline & & B & Std. Error & & & \\
\hline \multirow[b]{2}{*}{1} & (Constant) & .315 & .160 & & 1.974 & .049 \\
\hline & $\begin{array}{c}\text { MUET } \\
\text { Performance }\end{array}$ & .801 & .051 & .706 & 15.679 & .000 \\
\hline
\end{tabular}


From Table 6, there is an explanation and interpretation that can be reflected to relate the dependent variable and the independent variable. The finding shows that this coefficient level of emotional intelligence among the undergraduate students is 0.801 . Thus, for every unit in the level of the emotional intelligence among the undergraduate students' score, it is expected to get a 0.801-point increases in the students' MUET performance. This is statistically significant at $t$ $=15.68$ (Sig. $=.049<0.05)$.

Furthermore, a multiple regression analysis has been conducted to investigate whether the level of each subskill of Emotional Intelligence (EQ) among undergraduate students can predict the students' performance in MUET? This analysis is hoped to give a further explanation about the contribution of each subskill of EQ towards the students' MUET performance.

Table 7: Model Summary

\begin{tabular}{|c|c|c|c|c|}
\hline \hline \multicolumn{5}{|c|}{ Model Summary } \\
\hline Model & $\mathrm{R}$ & $\mathrm{R}$ Square & $\begin{array}{c}\text { Adjusted } \mathrm{R} \\
\text { Square }\end{array}$ & $\begin{array}{c}\text { Std. Error of } \\
\text { the Estimate }\end{array}$ \\
\hline 1 & $.722^{\mathrm{a}}$ & .522 & .512 & .57134 \\
\hline a. Predictors: (Constant), Empathy, Social Skills, Self-Regulation, Self-awareness, \\
Motivation \\
\hline b. Dependent Variable: Emotional Intelligence \\
\hline \hline
\end{tabular}

This value in Table 7 proves that $52.2 \%$ of the variances in the students' MUET performance can be predicted from the variable of each subskill of emotional intelligence. It can be summarized that the subskills of emotional intelligence which are motivation, empathy, self-regulation, self-awareness, and social skills can predict the students' MUET performance.

Table 8: Description of Multiple Regression

\begin{tabular}{|c|c|c|c|c|c|c|}
\hline \hline \multicolumn{2}{|c|}{ ANOVA $^{a}$} & & \\
\hline \multicolumn{2}{|c|}{ Model } & $\begin{array}{c}\text { Sum of } \\
\text { Squares }\end{array}$ & $\mathrm{df}$ & $\begin{array}{c}\text { Mean } \\
\text { Square }\end{array}$ & $\mathrm{F}$ & Sig. \\
\hline \multirow{3}{*}{1} & 86.974 & 5 & 17.395 & 53.287 & $.000^{\mathrm{b}}$ & 86.974 \\
\cline { 2 - 7 } & 79.650 & 244 & .326 & & & 79.650 \\
\cline { 2 - 7 } & 166.624 & 249 & & & & 166.624 \\
\hline \multicolumn{6}{|c|}{ a. Dependent Variable: MUET Performance } \\
\hline \multicolumn{6}{|c|}{ b. Predictors: (Constant), motivation, self-awareness, self-regulation, social skills, } \\
empathy
\end{tabular}

According to Table 8 , the p-value is 0.000 , which is lower than alpha level, $\mathrm{p}<$ 0.05 . It justifies that the subskills of emotional intelligence which are motivation, self-awareness, self-regulation, social skills, empathy can be used significantly to predict the students' MUET performance. The details of the interpretation are stated in table 9. 
Table 9: Description of Multiple Regression

\begin{tabular}{|c|c|c|c|c|c|c|}
\hline \multicolumn{5}{|c|}{ Coefficients ${ }^{a}$} & \multirow{3}{*}{$\mathrm{t}$} & \multirow{3}{*}{ Sig. } \\
\hline \multirow{2}{*}{\multicolumn{2}{|c|}{ Model }} & \multicolumn{2}{|c|}{$\begin{array}{c}\text { Unstandardized } \\
\text { Coefficients }\end{array}$} & $\begin{array}{l}\text { Standardized } \\
\text { Coefficients }\end{array}$ & & \\
\hline & & B & $\begin{array}{l}\text { Std. } \\
\text { Error }\end{array}$ & Beta & & \\
\hline \multirow{6}{*}{1} & (Constant) & .062 & .021 & & 2.937 & .004 \\
\hline & Self_Awareness & 200 & .008 & .259 & 24.753 & .000 \\
\hline & Self_Regulation & 193 & .007 & .236 & 27.050 & .000 \\
\hline & Empathy & 214 & .011 & .240 & 18.791 & .000 \\
\hline & Social_Skills & 196 & .007 & .241 & 27.397 & .000 \\
\hline & Motivation & .174 & .010 & 132 & 17.669 & .000 \\
\hline \multicolumn{7}{|c|}{ a. Dependent Variable: MUET Performance } \\
\hline
\end{tabular}

According to Table 9, there are several justifications and interpretation can be made based on the analysis of the multiple regression. The analysis can be deducted relating dependent variables and independent variables and as stated below:

This coefficient unit for the level of empathy is 0.21 . Hence, for every unit in the level of empathy score, it is expected to a 0.21 point increase the students' MUET performance. This is statically significant at $t=18.79$ (Sig. $0.000<0.05$ ). While for the social skills subskill, the coefficient for social skills is 0.19 . Hence, for every unit in the social skills subskill score, it is expected to get a 0.19 increase to the students' MUET performance. This is statically significant at $t=27.4$ (Sig. $0.000<$ 0.05). Next, for self-regulation, it shows that the coefficient for it is 0.19 . So, the students' MUET performance will increase by 0.19 point for every unit of selfregulation subskill score. This is statically significant at $\mathrm{t}=27.05$ (Sig. $0.000<0.05$ ). Furthermore, the coefficient unit for self-awareness is 0.2 and it is still expected to give an increase of 0.2 points in the students' MUET performance for every unit in the self-awareness score. This is statically significant at $\mathrm{t}=24.75$ (Sig. $0.000<$ 0.05 ). While for motivation, the coefficient for it is 0.17 . Due to this finding, for every unit of motivation subskill score, it is expected to get an increase of 0.17 point in the students' ${ }^{\prime}$ MUET performance. This is statically significant at $\mathrm{t}=17.67$ (Sig. $0.000<0.05$ ).

The results confirm the findings of Sakinah and Nooreen (2013) that stated that there was a positive relationship between emotional intelligence skills and the students' MUET performance. In their study, it validated that the positive relationship between MUET achievements and EQ subskills indicated that an increase in emotional intelligence could increase MUET accomplishments. Thus, it has been proven that emotional intelligence skills contribute to the achievement of the MUET performance. Hassan et al. (2012) hypothesised that there was a relationship between emotional intelligence and vocabulary knowledge. He reported that female students with high emotional intelligence level showed high vocabulary knowledge. He stated that EQ is a good predictor in vocabulary knowledge among ESL students. Thus, emotional intelligence skills have their roles in predicting the students' achievement in MUET as vocabulary knowledge is also tested in reading and speaking paper. 
Next, Parisa (2012) discovered that adapting emotional intelligence in classroom instruction had a positive effect on the students' level of writing performance. She stated that Aki (2006) has highlighted that the nature of language learning requires the learners and instructor to use interpersonal communication and also psychology. Thus, it is very crucial to have the EQ skills in language learning, such as the ability to recognise, comprehend and manage emotions. In reading, Parisa (2012) added that the readers' emotional sensitivity is developed to embrace the characters in the reading process. As a result, language learning can be more successful if emotional intelligence skills are instilled in the learning process. Then, the role of emotional intelligence on English learning as a second language was investigated by Maryam (2012). She pointed out that emotional intelligence and its dimensions predict the students' achievement in language learning. Thus, it can be summarised that emotional intelligence skills can predict the students' performance in second language learning.

Thus, all those obtained values have explained the direction of the relationship between the dependent variables and independent variables, either it decreases or increases. From the data inferred from the analysis, it can be summarized that the students' MUET performance will increase and become better when the level of emotional intelligence is higher. Every subskill of emotional intelligence has played its roles in determining the students' MUET performance. Again, based on the finding, the students' MUET performance will be improved and become better when each subskill level is improved and better as well.

\section{Conclusions}

This study has illustrated several significant findings regarding both the independent and dependent variables. This study also provided results for all the research questions. Generally, there is no significant difference in the level of emotional intelligence (EI) according to the students' programmes in the technical university. It has been found that there is a significant correlation between the level of emotional intelligence (EI) among the undergraduates in the technical university. The main implication derived from this study relates to the roles of emotional intelligence skills in English Language learning and the students' English performance. The shreds of evidence from this research suggest that emotional intelligence plays an important role in determining the students' language performance. Besides, the study has pointed out that students' MUET performance can be improved if the students have a higher level of emotional intelligence. Since emotional intelligence affects English Language performance, the integration of emotional intelligence skills should be implemented in every English course offered in the technical university. The findings also suggest on the need for the involvement of the stakeholders be it the management, faculties, lecturers and students in enhancing MUET performance, including the integration and implementation of the elements of emotional intelligence in the teaching and learning of English language. Nor Lailatul Azilah, Syed Najmuddin and Ruslan (2016) also proposed that EI can be instilled, taught and learned. As pontificated by Hen (2020), many kinds of research have proven the significance of emotional intelligence to career development, academic achievement and life satisfaction. Hence, this study suggests that English lecturers could benefit from 
emotional intelligence training programmes that offer the opportunity to develop knowledge and skills of emotional intelligence in English Language class. For future research, it is suggested to conduct a study on the relationship between emotional intelligence traits and language skills such as listening, speaking, reading and writing among the technical students.

\section{Acknowledgements}

The authors would like to thank the Centre of Languages and Human Development, Universiti Teknikal Malaysia Melaka (UTeM), Research Group CAct - PET for supporting this research. This research was supported by a Special Grant for Language Teachers from Universiti Teknikal Malaysia Melaka (KHASDG/2019/PBPI/Q00041).

\section{References}

Adeyemo, D. (2007). Moderating Influence of Emotional Intelligence on the Link Between Academic Self-efficacy and Achievement of University Students. Psychology and Developing Societies, 19(2). https://doi.org/10.1177/097133360701900204

Alavinia, P., \& Mollahossein, H. (2012). On the Correlation between Iranian EFL Learners' Use of Metacognitive Listening Strategies and Their Emotional Intelligence. International Education Studies, 5, 189-203. https://doi.org/10.5539/ies.v5n6p189

Al-Tamimi, A., \& Shuib, M. (2010). Investigating the English Language Needs of Petroleum Engineering Students at Hadramout University of Science and Technology, Asian ESP Journal, 6, 6-34.

Ashairi, S., Mohamed, Y. M. N., \& Melor, M. Y. (2017). Dual-Language Programme in Malaysian Secondary Schools: Are You Ready? Paper presented at the Seminar Serantau. Malaysia: Universiti Kebangsaan Malaysia, September. https://doi.org/10.17576/gema-2017-1704-09

Bar-On, R. (2007). Reuven Bar-On Organization. Retrieved March 20, 2010, from Reuven Bar-On Web Site: http://www.reuvenbaron.org/bar-on-model/essay.php?i=3

Chan, S. H., \& Wong, B. E. (2004). Assessing oral skills of pre-tertiary students: The nature of the communicative act. Proceedings of the International Conference on English Instruction and Assessment, pp. 33- 48. Taiwan: National Chung Cheng University.

Downey, L. A., Mountstephen, J., Lloyd, J., Hansen, K., \& Stough, C. (2008). Emotional intelligence and scholastic achievement in Australian adolescents. Australian Journal of Psychology, 60, 10-17.

Gibbs, N. (1995). Emotional Intelligence: The EI Factor. Time Magazine.

Goleman, D. (1995). Emotional Intelligence. New York: Bantam Books.

Goleman, D. (1998). In D. Goleman, Working with Emotional Intelligence. New York: Bantam Books.

Hamid, A. K. (2006). Panduan Meningkatkan Kecerdasan Emosi. Kuala Lumpur, pp. 2541.

Hassan, A., Sulaiman, T., \& Ishak, R. (2009). Philosophy Underlying Emotional Intelligence in Relation to Level of Curiosity and Academic Achievement of Rural Area Students. (U. Faculty of Educational Studies, Ed.) Journal of Social Science, 5(2), 95-103.

Hen, M. (2020). Teaching Emotional Intelligence: An Academic Course for Hospital Teachers. Continuity in Education, 1(1), 22-36. http://doi.org/10.5334/cie.13

Hen, M., \& Sharabi-Nov, A. (2014). Teaching the teachers: Emotional intelligence training for teachers. Teaching Education, 25(4), 375-390. https://doi.org/10.1080/10476210.2014.908838 
Huseyin, O., Mehmet, D., \& Jafar, P. (2015). Emotional Intelligence and Attitudes Towards Foreign Language Learning: Pursuit of Relevance and Implications. Procedia - Social and Behavioral Sciences, 416-423. https://doi.org/10.1016/j.sbspro.2015.04.118

Joesba, M., \& Ardeo, G. (2005), Student engineers, ESP courses, and testing with Cloze Tests. ESP World, 2 (10). Retrieved 15 April 2010, from http://www.espworld.info/contents.htm

Khalil, M. (2012). The relationship between EFL Iranian Learners' emotional intelligence and their performance on TOEFL/PBT. International Journal of Linguistics, 46-54. https://doi.org/10.5296/ijl.v4i1.1382

Marquez, P. G.-O., Martin, R. P., \& Brackett, M. A. (2006). Relating Emotional Intelligence to Social Competence and Academic Achievement in High School Students. Psicothema Online Journal, 18, 118-123.

Mayer, J. D. (2001). UNH. Retrieved 8 March 2010, from UNH Website: http://www.unh.edu/emotional_intelligence/EIAssets/EI2001Chapter\%201\%20fro $\mathrm{m} \% 20$ Emotional\%20Intelligence\%20in\%20Everyday\%20Life.pdf

Mayer, J. D., Salovey, P., \& Caruso, D. R. (2004). Emotional Intelligence: Theory, Findings and Implications. Psychological Inquiry, 15(3), 197-215.

Moses, E., \& Malani, I. (2019). Dual language programme: The perceptions and challenges of teachers and students in Klang, Selangor. Jurnal Pendidikan Sains Dan Matematik Malaysia, 99(1), 36-48. Retrieved from http://ojs.upsi.edu.my/index.php/JPSMM/article/view/3039

Nesari, A., Karimi, L., \& Filinezhad, N. (2011). On the Relationship between Emotional Intelligence and Vocabulary Learning of Iranian EFL Learners at the Intermediate Level. Procedia - Social and Behavioral Sciences, 28, 900-903. https://doi.org/10.1016/j.sbspro.2011.11.165

Noriah. (2004). Manual Iventori Kecerdasan Emosi Malaysia, IKEM (D) [Malaysian Emotional Intelligence Inventory Manual], Versi 2. Fakulti Pendidikan Universiti Kebangsaan Malaysia.

Noriah, M. I., Shaharuddin, A., Kadderi, M. D., \& Roslina, T. A. (2007). Kepintaran emosi sebagai faktor peramal pencapaian akademik peajar IPTA: implikasi terhadap kebolehpasaran [Emotional intelligence as a predictor factor of IPTA students' academic achievement: implications for marketability]. Jurnal Personalia Pelajar, 11, $1-28$.

Nor Lailatul Azilah, H., Syed Najmuddin, S. H., \& Ruslan, H. (2016). Examining the level of emotional intelligence among semester one students in Universiti Teknologi MARA Pahang. Journal of Human Capital Development, 9(1), 1-11.

Nur Sakinah, T., \& Nooreen, N. (2013). Relationship between MUET Test Achievement and Trait Emotional Intelligence among Matriculation Students. Graduate Research in Education, 354-358.

Orme, G. (2001). What Is Emotional Intelligence? In G. Orme, Emotionally Intelligent Living (pp. 3-24). Wales: Crown House Publishing.

Pendergrass, N., Kowalczyk, R., Dowd, J., \& Laoulache, R. (2001). Improving first year engineering education. Journal of Engineering Education. Retrieved 12 May 2008 from http://findarticles.com/p/articles/mi_qa3886/is_200101/ai_n8942238

Petrides, K., Mikolajczak, M., Mavroveli, S., Sanchez-Ruiz, M. -J., Furnham, A., \& PérezGonzález, J. C. (2016). Developments in Trait Emotional Intelligence Research. Emotion Review, 8. https://doi.org/10.1177/1754073916650493 
Petrides, K. V., Frederickson, N., \& Furnham, A. (2004). The role of trait emotional intelligence in academic performance and deviant behaviour at school. Personality and Individual Differences, 36, 277 - 293.

Pritchard, M., \& Nasr, A. (2004) Improving reading performance among Egyptian engineering students: Principles and practices. English for Specific Purpose, 23, 425445.

Rea-Dickins, P., \& Scott, C. (2007) Washback from language tests on teaching, learning and policy: evidence from diverse settings. Assessment in Education: Principles, Policy $\mathcal{E}$ Practice, 14(1), pages 1-7.

Reza, P. (2009). Emotional and verbal intelligence in language learning. Iranian Journal of Language Studies, 3(1), 43-64.

Rossiter, M. J. (2003). The effects of affective strategy training in the ESL classroom. TESLEJ, 7(2), 1-20.

Sanchez-Ruiz, M. J., Perez-Gonzales, J. C., \& Petrides, K. V. (2010). Trait emotional intelligence profiles of students from different university faculties. Australian Journal of Psychology, 62. 51-57.

Sanchez-Ruiz, M. J., Hernandez-Torrano, D., Perez-Gonzalez, J. C., Batey, M., \& Petrides, K. V. (2011). The relationship between trait emotional intelligence and creativity across different subject domains. Motivation and Emotion, 35, 461-473.

Sanchez-Ruiz, M. J, Mavroveli, S., \& Poullis, J. (2013). Trait emotional intelligence and its link to university performance: An examination.

Saud, W. I. (2019). Emotional intelligence and its relationship to academic performance among SAUDI EFL undergraduates. International Journal of Higher Education, 8(6), 222-230. https://doi.org/10.5430/ijhe.v8n6p222

Sedigheh, S., \& Ghasem, B. (2011). The Relationship between Emotional Intelligence and Language Proficiency of Iranian High School Students. Procedia Social and Behavioral Sciences, 1603-1607. https://doi.org/10.1016/j.sbspro.2011.10.311

Seyed Jalal, A. R., Hadi, H., \& Taghi, G. (2014). Investigating The Relationship between emotional intelligence and language achievement: A case of TEFL and Non-TEFL University Students. International Journal of Language Learning and Applied Linguistic World, 5(3), 117-127.

Stottlemayer, B. G. (2002) A conceptual framework for emotional intelligence in education: Factors affecting student achievement. PhD diss., Texas A\&M University-Kingsville

Venkatraman, G., \& Prema, P. (2007). English language skills for engineering students: A needs survey. ESP World, 3(16). Retrieved 15 April 2018 from http.//www.espworld.info/contents.htm. 